\title{
Economic theory and policy: a coherent post-Keynesian approach
}

\author{
Philip Arestis* \\ University of Cambridge, UK, and University of the Basque Country, Spain
}

This contribution focuses on a coherent new way of thinking about the macroeconomy in terms of both economic theory and economic policies. The central bank should focus on financial stability; for fiscal policy in the short term and in the long term to address demand issues is very important. Interest rate policy should be such that the real rate of interest is in line with trend rate of growth in the economy. Fiscal and monetary policies, though, should be coordinated closely. Major central bank cooperation and intervention in the foreign exchange market is necessary to control the exchange rate. Regional and industrial policies to create the required capacity are important, along with incomes policies, to contain inflationary/deflationary pressures. Distribution of income and wealth is another important policy dimension in view of its importance in terms of the great recession.

Keywords: economic theory, economic policies, post-Keynesian economics

JEL codes: $D 30, E 12, E 42, E 43, E 44, E 64$

\section{INTRODUCTION}

This contribution proposes a coherent new way of thinking about the macroeconomy in terms of both theory and economic policy. We discuss first the theoretical framework that underpins the relevant economic policies before we turn our attention to the economic policies themselves. In terms of the latter we argue that distributional effects and financial stability are two important policy dimensions, which have been ignored in the past, and should be seriously taken on board. ${ }^{1}$

After this short introduction, we turn our attention in Section 2 to our theoretical background, followed in Section 3 by the discussion of the objectives and instruments of economic policies that emerge from the theoretical framework. In the final part of this contribution, Section 4, we summarise and conclude.

* This contribution is a significant extension on our previous relevant publications, for example Arestis (1989; 2010) and Arestis/Sawyer (2010a; 2010b). I am very grateful to Malcolm Sawyer, Eckhard Hein and the participants to the FMM conference for helpful comments. The usual disclaimer applies.

1. Interest in both distributional effects and financial stability have surfaced recently in view of the 'great recession'. Arestis and Karakitsos (2011), for example, discuss both dimensions. Atkinson et al. (2011) and Van Treeck (2012) concentrate more on the distributional effects dimension. 


\section{THEORETICAL FRAMEWORK}

The constituent elements of the model we put forward are discussed below. The model is divided into five blocks as follows.

\subsection{Block I: aggregate demand and supply}

This block is based on the proposition that the level of national income is determined by the level of aggregate demand. The latter is the sum of consumer demand, investment demand and government expenditure plus net exports, as in Equation (2.1): ${ }^{2}$

$$
Y=C+I+G+(X-Q)
$$

where $Y$ is national income, $C$ is consumption, $I$ is investment, $G$ is government expenditure, $X$ is exports and $Q$ is imports, and thus $(X-Q)$ is net exports $(N E)$. Aggregate demand is important in both the short run and the long run for the evolution of the economy. There is no market-based mechanism whereby market forces would propel the level of aggregate demand to any specific level of output and/or supply-side determined equilibrium.

We examine the components of aggregate demand next, beginning with consumption, as in Equation (2.2):

$$
\begin{aligned}
& C=C\left[\left(W E(1-t w), \Pi(1-t \pi), R, \Delta B L P_{h}\right]\right. \\
& +\quad+\quad+
\end{aligned}
$$

where $W$ is wages, $E$ total employment, so $W E$ is the wage bill, $t w$ is the tax rate on wages, $\Pi$ is total profits, $t \pi$ is the tax rate on profits, $R$ is the rate of interest on loans, and $\triangle B L P_{h}$ is changes in bank lending to households. The availability of credit to households influences consumption since expenditure has to be financed and some households are credit constrained. The sign under the variables indicates the partial derivative of $C$ with respect to the relevant independent variable. The independent variables are presumed to have a positive effect on the dependent variable with the exception of $R$, which has a negative effect. We treat $t w$ and $t \pi$ as exogenous and the rest of the variables are endogenised as explained below in the relevant blocks.

Investment expenditure is taken to be:

$$
\begin{gathered}
I=I\left(\Pi / K, Y / Y a, R, \Delta B L P_{f}\right) \\
+\quad+\quad-\quad+\quad+
\end{gathered}
$$

where the symbols are as above with the exception of $K$, which is capital stock, $\triangle B L P_{f}$ that stands for changes in bank lending to firms, and $Y a$, which is a measure of capacity output (further discussed below). All the variables affect investment positively, with the exception of $R$. For simplicity, the rate of interest on loans to households and to firms are taken as closely related, such that the use of a single rate of interest on loans in Equations (2.2) and (2.3) is thereby justified. Government

2. In what follows, capital letters indicate the level of the relevant variable while lower-case letters stand for the rate of change of the relevant variable. 
expenditure $(G)$, as in Equation (2.1), is treated as a policy variable and further examined in Block IV.

Net exports $(X-Q)$ are as in Equation (2.4):

$$
\begin{gathered}
X-Q=X(W T, R E R)-Q(Y, R E R)=N E \\
+\quad+\quad+\quad+
\end{gathered}
$$

where $W T$ is world trade, RER is real exchange rate, and the rest of the symbols are as above with all these variables in real terms. With the exception of the negative impact of the real exchange rate on exports $(X)$, the rest of the independent variables have a positive impact on net exports, denoted as $N E$ in Equation (2.4) and further examined in Block V. The foreign sector is, therefore, viewed as a significant aspect for the aggregate demand in terms of the imports and exports. The latter are included in the aggregate demand equation to also account for the effects on demand (and hence employment) of variations in the exchange rate.

There is also the supply side of the economy, which is reflected in a range of ways. The level of economic activity (as set by the level of demand) relative to the supply potential of the economy impacts on investment, as in Equation (2.3) above, and pricing decisions, as in Equation (2.14) below. The supply potential evolves over time as investment occurs; and it depends on the size and structure of the capital stock and the labour force. The relationship between wages and prices, and the inflationary forces in the economy, depend on the nature of the supply side of the economy and how it interacts with demand. The potential level of output at the level of the firm depends on, in a production function manner, the inputs of labour, capital, etc., which can be deployed by the firm and the state of technology. At the aggregate level, it is assumed that there is a comparable relationship, but it must be recognised that there are severe issues of aggregation and that the structure of the capital stock will also influence the supply potential. This aggregate supply output $(Y s)$, which could be produced, depends on employment of labour, the capital stock and the state of technology, as in Equation (2.5):

$$
\begin{array}{r}
Y s=Y s(E, K, S T) \\
+++
\end{array}
$$

where $E$ is employment, $K$ is some measure of capital stock, and $S T$ is state of technology. Actual output produced is taken to be demand-determined, and the production equation can be inverted to give employment for a given level of (demand determined) output as in Equation (2.6):

$$
\begin{gathered}
E=E(Y, K, S T) . \\
+++
\end{gathered}
$$

In this formulation, changes in demand $(Y)$, capital stock and technology have a positive effect on employment.

A benchmark level of output from a supply perspective is defined $(Y a)$, which is a capacity measure corresponding to the 'desired' level of operation (by firms), so that:

$$
\begin{array}{r}
Y a=Y a(K, S T) \\
++
\end{array}
$$


and $Y a$ would change over time in the same direction as capital stock and technology change. There is a level of employment corresponding to $Y a(E a)$, which would be as in Equation (2.8):

$$
\begin{gathered}
E a=E(Y a, K, S T) . \\
+\quad+\quad+
\end{gathered}
$$

$Y a$ is taken as a benchmark for firms' investment decisions: when $Y>Y a$ firms feel themselves to be working at over-capacity and encouraged to invest; but when $Y<Y a$ they are thereby discouraged from investment. For a given level of $K$ and $S T$, it is envisaged that the relationship between productivity $(Y / E)$ and $E$ is such that $Y / E$ initially rises as $E$ rises, then flattens out, and eventually declines.

It is clear from this analysis that aggregate demand and aggregate supply are not necessarily moved towards each other in the long run by the market mechanism. Indeed, how aggregate demand and supply evolve over time depends on the parameters involved. Aggregate demand is influenced by a number of factors over time, such as wage and price changes along with the consequent changes in the distribution of income between wages and profits. Aggregate supply also evolves over time and depends on the parameters as shown in Equation (2.6), in a way that is completely independent of those of aggregate demand. Clearly, in this analysis distributional aspects are relevant and important. We turn to this aspect next.

\subsection{Block II: distributional aspects and the inflationary process}

The interaction of the determinants of the profit rate, price and wage rates produces the distributional aspects of our theoretical framework. We begin with the profit rate $(\pi)$ function as in Equation (2.9):

$$
\begin{gathered}
\pi=\pi\left[(P-U L C), Y, R, D R_{f}\right] \\
+\quad+--
\end{gathered}
$$

where the profit rate is a function of the difference between the price level $(P)$ and the unit labour cost $(U L C)$, both in logarithmic form of their levels, which affects the rate of profit positively; output, also affecting the rate of profit positively, and the rate of interest, which affects $\pi$ negatively. This reinstates the significant role of commercial banks in the investment/saving process, and is further explored in Block III. The debt ratio of firms $\left(D R_{f}\right)$, defined as total debt to total assets, also affects $\pi$ negatively.

The $U L C$ is defined next, as in Equation (2.10), where again the variables are in logarithmic form of their levels:

$$
U L C=W-P R
$$

so that $U L C$ is defined as the difference between wages $(W)$ and productivity $(P R)$. We assume that productivity is exogenously determined with the wage level endogenously determined.

Equation (2.11) endogenises wages through its rate of change $(w)$ :

$$
\begin{gathered}
w=w\left\{\left[(W / P)^{d}-(W / P)\right],(Y-Y a), p, U, \pi, w^{e}\right\} . \\
+\quad+\quad+-++
\end{gathered}
$$


The rate of change of wages in Equation (2.11) is based on the bargaining position of workers as their desired real wage $\left[(W / P)^{d}\right]$ deviates from the actual real wage $(W / P)$. It is also influenced by the difference between actual and 'desired' output $(Y-Y a)$, inflation $(p)$, unemployment $(U)$, where unemployment is taken as a percentage of the labour force, by profitability $(\pi)$, and wage expectations $\left(w^{e}\right)$. The main hypothesis underpinning Equation (2.11) is that workers, unionised or non-unionised, bargain for a 'desired real wage'.

The next step is the determination of unemployment $(U)$ as in Equation (2.12).

$$
U=U[(Y-Y a), P R] .
$$

Unemployment in Equation (2.12) is related to the difference between actual and 'desired' output $(Y-Y a)$ and to productivity $(P R)$.

Turning to the inflationary process, we emphasise that inflation is multi-causal and the sources of inflationary pressure vary over time and economy. The inflation process is predicated on the premise that the price of output is a mark-up on the remuneration of the variable cost of production, which is labour, as shown in Equation (2.13):

$$
\begin{gathered}
p=p\left[w,(Y-Y a), p r, e r, p_{r m}, p^{e}\right] \\
+\quad+\quad-\quad-++
\end{gathered}
$$

where inflation $(p)$ is positively related to the rate of change of the nominal wage rate, $w$, to the difference between actual and 'desired' output $(Y-Y a)$, and it is negatively related to the rate of change of productivity $(p r)$ and to the rate of change of the nominal exchange rate $(\mathrm{er})$. It is also positively related to the growth rate of the prices of raw materials $\left(p_{m}\right)$ and to price expectations $\left(p^{e}\right)$.

Finally, for this block, the growth rate of the prices of raw materials is determined as in Equation (2.14):

$$
\begin{gathered}
p_{r m}=p_{r m}(e r, W T) . \\
-\quad+
\end{gathered}
$$

Equation (2.14) makes the growth rate of the prices of raw materials a function of the growth rate of the exchange rate (er), affecting it negatively, and depend on world trade $(W T)$ in a positive way. The latter two variables that are relevant to the open economy case are examined further below in Section 2.6.

\subsection{Block III: money and credit}

The money, credit and finance sector is an essential and important part of the macroeconomic framework under discussion. Money is endogenously determined within the private sector with the liquidity preference of banks providing a crucial role in the determination of the money stock. In the process, loans provided by banks themselves generate bank deposits. The central bank sets the key policy interest rate, which governs the terms upon which the central bank provides the 'base' money to the banking system.

The expansion of the stock of money is driven by the demand for loans, which leads to the expansion of bank deposits in so far as the demand for loans is met by the 
banking sector. Changes in the money supply can then come about through changes in bank deposits to the government and to the public. We can, thus, have in Equation (2.15):

$$
\Delta M=\triangle B D G C+\triangle B D P
$$

where changes in the money supply $(\Delta M)$ is the sum of changes in bank deposits to the government including currency $(\triangle B D G C)$ and changes in bank deposits to the public $(\triangle B D P)$.

$\triangle B D G C$ is a small fraction of the total money supply and we treat it as the residual in the identity described by Equation (2.16):

$$
\triangle B D G C=\triangle B L P+\triangle B L G+\triangle B L E S-\triangle B D P .
$$

Equation (2.16) then defines $\triangle B D G C$ as the sum of changes in bank lending to the public $(\triangle B L P)^{3}$ and to the government $(\triangle B L G)$, as well as of changes in bank lending to the external sector including other non-bank lending $(\triangle B L E S)$, minus $\triangle B D P$. $\triangle B L E S$ is treated as an exogenous variable and with $\triangle B L G$ endogenised in Block IV (see Equation (2.20)), the rest of the variables of Equation (2.16) are endogenised as explained immediately below.

We begin with $\triangle B L P$ as in Equation (2.17):

$$
\begin{array}{r}
\Delta B L P=\Delta B L P\left(\Delta Y, \Delta R, \Delta C R_{R}\right) . \\
+\quad-\quad-
\end{array}
$$

$\triangle B L P$ is hypothesised to depend on changes in the level of income $(\Delta Y)$ reflecting requirements for funding as the level of economic activity changes; the cost of borrowing is captured by changes in the rate of interest $(\Delta R)$. The variable $\Delta C R_{R}$ in Equation (2.17) stands for policy variables, which can affect credit directly. The best example for this variable is credit-rationing by the authorities. This possibility can occur when the demand for bank lending exceeds the available supply, or when commercial banks refuse to lend to more-risky customers who are judged as imprudent in terms of their borrowing behaviour. This is a variable that could be used to proxy financial stability influences as discussed in Section 3.

The other variable in Equation (2.16) that we endogenise is $\triangle B D P$, as in Equation (2.18):

$$
\begin{array}{r}
\Delta B D P=\Delta B D P(\Delta Y, \Delta R, X) \\
+\quad-\quad-
\end{array}
$$

where $\triangle B D P$ depends on changes in the level of income $(\Delta Y)$, reflecting the flow of funds into the banking sector as a result of changes in the level of economic activity. It also depends on changes in the rate of interest on loans $(\Delta R)$, which is hypothesised to account for possible portfolio effects: it proxies the relative attractiveness of alternative financial assets available to depositors as the market rate of interest changes. $X$ is an exogenous variable, which provides another possible avenue for financial stability variables as discussed in Section 3.

3. Clearly, $\triangle B L P$ aggregates the bank lending needs to industry $\left(\triangle B L P_{f}\right)$, consumers and other (non-commercial bank) financial institutions $\left(\Delta B L P_{h}\right)$. 
The market interest rate $(R)$ is determined as in Equation (2.19).

$$
\begin{gathered}
\Delta R=\Delta R(\Delta B R, \Delta E F, \Delta P D C) . \\
+\quad+\quad+
\end{gathered}
$$

Changes in the bank rate $(\Delta B R)$, as set by the monetary authorities, influence directly changes in the market interest rate $(\Delta R)$ via a mark-up. Two further variables are present: $\triangle E F$ to account for changes in external flows that can have an impact on market interest rates $(\Delta R)$; and $\triangle P D C$, which stands for sales of public debt to the nonbank public including currency. The variable is included to capture the influence of open-market operations on market interest rates; as such it is treated as exogenous. We examine next the government sector in Block IV.

\subsection{Block IV: government sector}

We begin our discussion of this block with the $\triangle B L G$ variable, which is determined through the government budget identity as shown in Equation (2.20):

$$
\triangle B L G=P S B R+\triangle E F-\triangle N B C
$$

where $P S B R$ stands for the public sector borrowing requirements, $\triangle E F$ stands for changes in external financing, and $\triangle N B C$ stands for sales of public debt to non-bank public including currency. Equation (2.21) reflects institutional arrangements, where normally that part of the government's borrowing requirement, which is not financed by the sale of debt outside the banking system, is met by the sale of debt - in particular Treasury bills - to the banking system. The latter acts, thereby, as the residual source of borrowing for the government. We treat $\triangle E F$ and $\triangle N B C$ as exogenous and discuss PSBR next.

$P S B R$, as portrayed in Equation (2.21), is simply defined as the difference between government expenditure $(G)$ and tax revenues $(T)$ :

$$
P S B R=G-T .
$$

We hypothesise $G$ and $T$ to be determined as shown below in Equations (2.23) and (2.25) respectively. Equations (2.20) and (2.21) are important ingredients of Block IV, which integrate the banking system with the government sector. The existence of a banking system implies that money is provided to the private sector through credit creation. The government supplies currency to the private sector by 'financing' government expenditure. It is the case that the banking sector cannot provide currency independently from the government.

Indeed, government expenditure $(G)$ creates deposits at the central bank; and payment of taxes $(T)$ reduces them. Any change in $(G-T)$ in Equation (2.21) changes the $P S B R$, which affects $\triangle B L G$ via Equation (2.20), and via Equation (2.16) with $\triangle B D G C$ changing, the money supply is affected. But by accepting bank deposit money, the government agrees de facto to advance credit; in effect it is currency that discharges the difference $(G-T)$ to banks via the central bank. We examine next $G$ and $T$. $G$ is determined as in Equation (2.22):

$$
G=P_{G} Q_{Q}+W E_{G}+U U_{B}+I D
$$

where the symbols are as above with the exception of $P_{G}$, the prices paid by the government for goods and services bought by the government $\left(Q_{Q}\right), E_{G}$ that stands for the 
number of employees in the government sector, $U_{B}$ is unemployment benefits, and $I D$ that stands for interest payments on government debt. $E_{G}$ is defined as in Equation (2.23):

$$
E_{G}=E-E_{P}-U
$$

where $E$ is the total working population, as defined above for the purposes of Equation (2.2), and $E_{P}$ is employment in the private sector. Clearly, $E_{G}+E_{P}=E$, that is total employment.

We may also endogenise $T$ simply as in Equation (2.24):

$$
\begin{array}{r}
T=T(Y) \\
+
\end{array}
$$

where Equation (2.24) accounts for tax rates and therefore represents tax policy.

\subsection{Block V: open economy aspects}

We begin with the variable $\Delta E F$ - that is, changes in external financing as in Equation (2.25), which provides essentially the main ingredients to Block V:

$$
\Delta E F=C B+\triangle K M-O E F
$$

where $\triangle E F$ is equal to the current balance of international payments $(C B)$ plus changes in capital movements $(\triangle K M)$ minus other external financing $(O E F)$; the latter variable includes external lending to the public sector plus domestic bank lending to the public sector in foreign currencies. We treat $O E F$ as exogenous and endogenise $C B$ and $\triangle K M$. We begin with $C B$ as in Equation (2.26):

$$
\begin{gathered}
C B=N E+O C B=X(W T, R E R)-Q(Y, R E R)+O C B \\
+\quad-\quad+\quad+
\end{gathered}
$$

where the symbols are as above, with the exception of $O C B$, which stands for other earnings on foreign investments minus payments made to foreign investors and cash transfers; this latter variable is treated as exogenous.

Next, we endogenise $\Delta K M$ as in Equation (2.27):

$$
\begin{gathered}
\Delta K M=\Delta K M\left[\left(R / R_{W}\right), E(e r)\right] . \\
+
\end{gathered}
$$

The ratio of domestic interest rates $(R)$ to world interest rates $\left(R_{W}\right)$ is included on the assumption that capital flows are sensitive to returns available internationally. These returns, however, are not captured simply by interest rates but, perhaps more importantly, by expected exchange rate movements, hence the inclusion of the expected rate of change of the nominal exchange rate $E(e r)$.

Finally, the real exchange rate (RER) is endogenised as in Equation (2.28):

$$
\begin{gathered}
R E R=R E R\left[\left(R / R_{W}\right), Y, W T, E(e r)\right] \\
+\quad+\quad+\quad+
\end{gathered}
$$

where the variables are all as above. Clearly, with the exception of domestic income $Y$, all the other variables have a positive impact on the real exchange rate. 


\section{OBJECTIVES AND INSTRUMENTS OF ECONOMIC POLICIES}

\subsection{Objectives of economic policies}

The overall focus of economic policies should be on sustainable and equitable economic development and growth. A specific part of this general focus is the objective of the achievement of full employment of the labour force. Achieving such an objective requires the maintenance of both a high level of aggregate demand and the provision of sufficient productive capacity. The development and analysis of economic policies arise from interactions between those macroeconomic objectives and the theoretical framework outlined above. A number of economic policy objectives follow from our analysis. These are:

(i) full employment of the available labour supply, and thus sustainable growth;

(ii) a constant rate of inflation consistent with output growth rather than a target rate of inflation; and this in view of the evidence that inflation and output move together up to around a $10-15$ per cent inflation rate; ${ }^{4}$

(iii) fair distribution of income and wealth; and

(iv) financial stability.

We discuss the instruments of economic policy next in Section 3.2.

\subsection{Instruments of economic policies}

A number of economic policies follow in view of the theoretical framework discussed above.

(1) Fiscal policy is paramount both in the short run and in the long run (Arestis 2009; 2012; Arestis/Sawyer 2006). In the short term, variations in the fiscal stance can be used in conjunction with automatic stabilisers to offset fluctuations in economic activity arising from, inter alia, variations in private sector aggregate demand. ${ }^{5}$ In the longer term, the general fiscal stance should be set to underpin the desired level of output and employment.

Recent evidence is very supportive of this view. The IMF World Economic Outlook makes the following point in relation to fiscal multipliers (IMF 2012: 42): 'The main finding, based on data for 28 economies, is that the multipliers used in generating growth forecasts have been systematically too low since the start of the Great Recession, by 0.4 to 1.2 , depending on the forecast source and the specifics of the estimation approach. Informal evidence suggests that the multipliers implicitly used to generate these forecasts are about 0.5 . So actual multipliers may be higher, in the range of 0.9 to 1.7 '. Another IMF publication (Batini et al. 2012) supports fiscal policy even more strongly. The most relevant result in this context is that expenditure multipliers are larger than tax multipliers. In downturns, expenditure multipliers are ten times larger than tax multipliers, and in expansions they are six times larger. The fiscal multipliers reported are in line with the ones reported in the IMF's World Economic

4. The evidence is provided by Ferguson (2005); see, also, Ghosh/Phillips (1998) and Khan/ Senhadji (2001).

5. It should be noted, though, that automatic stabilisers can change. Creel and Saraceno (2008), for example, suggest that automatic stabilisers in the EU have actually diminished recently. 
Outlook for October 2012 (IMF 2012), if not higher. In view of these results, Batini et al. (2012: 32) suggest that 'Large consolidations make recessions more likely even when made at an expansion time'.

This approach raises the issue of sustainability of the deficit (see Arestis/Sawyer 2006), which we view as not a significant issue for two basic reasons. First, in this approach, and in the model above, governments borrow because private sector wishes to lend; if there were no potential excess of savings over investment, then there would be no need for a budget deficit. Saving, over and above investment, can only be realised if there is a budget deficit or overseas lending, which absorbs those savings. Second, a total budget deficit of $d$ (relative to GDP) is always sustainable in the sense that the corresponding debt-to-GDP ratio $(b)$ stabilises at: $b=d / g$ with $g$ as the growth rate. The budget deficit, which is relevant for the level of demand, is the overall budget position rather than the primary deficit (or surplus). To the extent that a budget deficit is required to offset an excess of private saving over investment, then it is the overall budget deficit which is relevant. Bond interest payments are a transfer payment and add to the income of the recipient, which is similar in that respect to other transfer payments; though the propensity to consume out of interest payments is likely to be less than that out of many other transfer payments. In terms of sustainability, then, of a fiscal deficit, the condition is generally readily satisfied, this being the requirement of a positive nominal growth rate. Consequently, we may summarise the argument by suggesting that a budget deficit, including interest payments, which bears a constant relationship to GDP, is sustainable. In fact, it leads to a debt-GDP ratio equal to the deficit-GDP ratio divided by the growth of nominal GDP.

(2) Interest rate policy should be set so that the real rate of interest is as low as possible, but in line with the trend rate of growth (see, also, Arestis/Saywer 2010b). The simplest way to implement such a policy would be to set the nominal policy interest rate at the beginning of the year, taking into account the expected rate of inflation for the coming year (with perhaps some adjustment based on difference between actual and expected inflation in the preceding year). There are some issues with such a policy approach to be resolved. The arguments for a constant real rate equal to the rate of growth relate to some market rate of interest, which is not equal to the policy rate, and which may bear a varying relationship with the policy rate. There can be complications in so far as the domestic interest rate differs from world interest rates, which can have implications for the exchange rate. This is neither to suggest some simple uncovered interest rate parity idea nor to argue that the effects of interest rate differentials on exchange rate are firm and predictable.

We may note at this stage that, in terms of economic policies to tackle inflation, our approach is rather unconventional in the following sense. We take the view that price stability need not be the focus of economic policy, in view of the fact that the causes of inflation vary and also that inflation is not always harmful to growth, as argued above. In this sense, there is no need to develop policies to tackle inflation unless it reaches high levels. Such an approach involves the development of an incomes policy to contain inflation when it reaches unacceptably high rates. If at the same time one wishes to propose a permanent incomes policy, this could be done as follows. Targeting some desired rate of inflation and preventing deviations from this in the upward but also in the downward direction in order to prevent deflationary tendencies becomes the right permanent incomes policy.

(3) Coordination of fiscal and monetary policies is paramount with a great deal of evidence to support it. Arestis (2012), when reviewing the relevant empirical evidence, concludes that under fiscal and monetary policy coordination fiscal multipliers are 
higher than when no policy coordination prevails. This contribution would suggest that macroeconomic stability is the joint responsibility of the monetary and fiscal authorities. Potentially destabilising behaviour by one authority can be offset by an appropriate stance of the other authority. Perhaps more importantly, the monetary authority can trade off some inflation for lower unemployment, even in the long run.

(4) The operations of the central bank should ultimately be directed towards financial stability. Such focus should entail a new toolkit, which should incorporate both macroprudential and microprudential instruments. Both instruments should be under the banner of the policymakers avoiding rules and employing judgement and thus discretion. The macroprudential toolkit should account for the potential failures of the system: low levels of liquid assets; inadequate levels of capital with which to absorb losses; too big a financial sector; too leveraged a sector with high risks to the taxpayer and the economy. Thus, macroprudential financial instruments should be able to control the size, leverage, fragility and risks of the financial system. Microprudential instruments relate to the structure and regulation of individual banks. Banks that are 'too big to fail' should be cut down in size; guarantees to retail depositors should be limited to banks with a narrower range of investments; risky banks to taxpayers and the economy should face higher capital requirements; large and complex financial institutions can be wound down in an orderly manner; and large banks should not be allowed to combine retail banking with risky investment business (see, also, Turner 2010). Possibly, all the elements just suggested could be combined. In Section 2.3 (Block III), part of of the discussion of our model, we indicate the relationships that can be utilised for financial stability purposes.

(5) Securing a stable exchange rate is important. This requires significant intervention along with international cooperation and agreement. Indeed, this is particularly relevant for stability between the major currencies. The argument normally used to justify that appreciation in the exchange rate would slow inflation is no longer supported empirically. The impact of interest rate changes has become ambiguous in this respect. It would appear to be the case that capital movements are based more on equities rather than on other assets. A change in interest rates may then have the opposite effect on capital movements than otherwise (Angeriz/Arestis 2007). In any case, the argument sketched above points in the direction of setting a real interest rate broadly in line with the rate of growth. In view of this argument, the interest rate could not be varied for exchange rate purposes. It should be recognised, though, that the general global level of interest rates may constrain the domestic rates. Despite the lack of evidence supporting uncovered interest rate parity, the degree to which a country's real interest rate could persistently diverge from real interest rates around the world is unclear. Consequently, it becomes difficult for any single country to secure a stable exchange rate without tightly controlling it, thereby capital controls become part of a very suitable and relevant economic policy in the case of an open economy.

(6) Given the way we model the supply side of the economy, it is paramount that relevant policies should be in place for this purpose. We would suggest that industrial and regional policies are required to ensure that supply constraints are absent. Public expenditure, particularly investment, can also be structured to ease supply constraints. There is often a mismatch between available productive capacity and the labour force, and its geographical distribution; higher levels of employment require more productive capacity. These arguments add a great deal of substance to the coordination of economic policies.

(7) Policies to account for inequalities are paramount. Not only should economic policies focus on achieving full employment but also to mitigate inequality. The policies 
discussed in this sub-section should all be geared towards this policy objective. Perhaps the most important economic policy in this respect is fiscal policy. Targeting social spending, including people's investment in skills and education, is paramount from the government spending point of view. A related study is the one by Muinelo-Gallo and Roca-Sagalés (2011). The authors employ an endogenous growth model that incorporates fiscal policy and economic growth along with their effects on income inequality. Pooled-panel estimations are undertaken for 43 upper-middle and highincome countries for the period 1972-2006 to conclude that increases in public investment expenditure reduce inequality without harming output, regardless of whether they are financed through direct or indirect taxes. Other forms of public expenditure are shown not to be as effective as the public investment expenditure.

Reforming taxes to make them fairer is another important aspect of fiscal policy. A further example, and priority, is the removal of subsidies for the 'too-big-to-fail' financial insitutions (see, also, The Economist 2012). Such a policy initiative would help to remove, to a large extent, one of the main contributory factors to the surge in wealth at the top of income distribution and to the financial sector in particular. This inequality, as we have argued elsewhere (Arestis/Karakitsos 2011), was one of the main causes of the 'great recession'.

\section{SUMMARY AND CONCLUSIONS}

We have put forward a new theoretical framework, which entails a number of economic policies. Such policies that emanate from our theoretical framework can be succinctly summarised. Use fiscal policy in the short term and in the long term to address demand issues. Interest rate policy should be such that the real rate of interest is in line with the trend rate of growth in the economy. Fiscal and monetary policies, though, should be coordinated closely. The central bank should focus on financial stability, which we have argued requires close coordination between the central bank and other economic policy agents. Major central bank cooperation and intervention in the foreign exchange market is necessary to control the exchange rate. Employ regional and industrial policies to create the required capacity. In terms of inflation, and given its uncertain relationship to growth, inflationary pressures should only worry economic policymakers when they are substantial. Developing incomes policies to contain such serious inflationary pressures is relevant. In the pursuit of the economic policies just summarised, it is of vital importance to account properly and fully for distributional effects, one of the main causes of the 'great recession'.

\section{REFERENCES}

Angeriz, A., Arestis, P. (2007): Monetary policy in the UK, in: Cambridge Journal of Economics, 31(6), 863-884.

Arestis, P. (1989): On the Post Keynesian challenge to neo-classical economics: a complete quantitative macro-model for the UK economy, in: Journal of Post Keynesian Economics, 11(4), 611-629.

Arestis, P. (2009): Fiscal policy within the NCM framework, in: Creel, J., Sawyer, M. (eds), Current Thinking on Fiscal Policy, Houndmills, Basingstoke: Palgrave Macmillan, 6-27.

Arestis, P. (2010): Economic policies after the new concensus macroeconomics, in: Dullien, S., Hein, E., Truger, A., van Treeck, T. (eds), The World Economy in Crisis - The Return of Keynesianism?, Marburg: Metropolis, 271-294. 
Arestis, P. (2012): Fiscal policy: a strong macroeconomic role, in: Review of Keynesian Economics, 1(1), 93-108.

Arestis, P., Karakitsos, E. (2011): An analysis of the causes of the 'Great Recession' and some policy implications, in: Niechoj, T., Onaran, Ö., Stockhammer, E., Truger A., van Treeck, T. (eds), Stabilising an Unequal Economy? Public Debt, Financial Regulation, and Income Distribution, Marburg, Germany: Metropolis-Verlag, 63-80.

Arestis, P., Sawyer, M. (2006): Fiscal policy matters, in: Public Finance, 54(1), 133-153.

Arestis, P., Sawyer, M. (2010a): 21st century Keynesian economic policy, in: Arestis, P., Sawyer, M. (eds), 21st Century Keynesian Economics, Annual Edition of International Papers in Political Economy, Houndmills, Basingstoke: Palgrave Macmillan, 81-119.

Arestis, P., Sawyer, M. (2010b): What monetary policy after the crisis?, in: Review of Political Economy, 22(4), 499-515.

Atkinson, A.B., Piketty, T., Saez, E. (2011): Top incomes in the long run of history, in: Journal of Economic Literature, 49(1), 3-71.

Batini, N., Callegari, G., Melina, G. (2012): Successful austerity in the United States, Europe and Japan, IMF Working Paper WP/12/190, Washington, DC: International Monetary Fund, URL: http://www.imf.org/external/pubs/ft/wp/2012/wp12190.pdf.

Creel, J., Saraceno, F. (2008): Automatic stabilisation, discretionary policy and the stability pact, in: Creel, J., Sawyer, M. (eds), Current Thinking on Fiscal Policy, Houndmills, Basingstoke: Palgrave Macmillan, 112-144.

Economist, The (2012): Policy prescription: a true progressivism, Special Report: World Economy, 13 October.

Ferguson, R. (2005): Monetary credibility, inflation, and economic growth, Speech at the Cato Institute 23rd Annual Monetary Conference on Monetary Institutions and Economic Development, Washington, DC, 3 November.

Ghosh, A., Phillips, S. (1998): Warning: inflation may be harmful to your growth, in: IMF Staff Papers, 45(4), 672-710.

IMF (2012): Coping with high debt and sluggish growth, in: World Economic Outlook, October, Washington, DC: International Monetary Fund.

Khan, M.S., Senhadji, A.S. (2001): Threshold effects in the relationship between inflation and growth, in: IMF Staff Papers, 48(1), 1-21.

Muinelo-Gallo, L., Roca-Sagalés, O. (2011): Economic growth and inequality: the role of fiscal policies, in: Australian Economic Papers, 50(2-3), 74-97.

Turner, A. (2010): What do banks do? What should they do and what public policies are needed to ensure best results for the real economy?, Speech given at the CASS Business School, 17 March, URL: http://www.fsa.gov.uk/pubs/speeches/at_17mar10.pdf.

Van Treeck, T. (2012): Did inequality cause the U.S. financial crisis?, Working Paper 91, Düsseldorf, Germany: Macroeconomic Policy Institute (IMK). 